\title{
Optimization of Maintenance Activity Using the World-Class Maintenance System in Skidder Forest Operations
}

\author{
Carlos Cézar Cavassin Diniz ${ }^{1}$, Diellen Lydia Rothbarth ${ }^{1}$, Eduardo da Silva Lopes ${ }^{2}$, \\ Gabriel de Magalhães Miranda ${ }^{2}$, Henrique Soares Koehler ${ }^{1} \&$ Gustavo Silva Oliveira $^{1}$ \\ 1 Programa de Pós-graduação em Engenharia Florestal, Departamento de Economia e Extensão Rural, \\ Universidade Federal do Paraná, Curitiba, Paraná, Brazil \\ ${ }^{2}$ Universidade Estadual do Centro-Oeste, Irati, Paraná, Brazil \\ Correspondence: Carlos Cézar Cavassin Diniz, Programa de Pós-graduação em Engenharia Florestal, \\ Departamento de Economia e Extensão Rural, Universidade Federal do Paraná, Av. Prefeito Lothário Meissner, \\ 632-Jardim Botânico, Curitiba, Paraná, Brazil. Tel: 42-998-290-707. E-mail: carlos.diniz@ufpr.br
}

Received: March 17, 2019

doi:10.5539/jas.v11n10p162
Accepted: May 13, 2019 Online Published: July 15, 2019

URL: https://doi.org/10.5539/jas.v11n10p162

\begin{abstract}
The objective of this paper was to evaluate technical and economically the use of a world-class maintenance system (WCM) in the forest skidding operations. The study was performed in a forest company located in the state of Paraná, inside forest plantations of Pinus taeda and Eucalyptus grandis. For the purpose of analysis, the mechanical availability, hydraulic oil consumption, average time between failures, average repair time, proactive maintenance index and maintenance costs were evaluated during 18 months, considering the stages of implantation, maturation and stabilization of the WCM system. As a result, there was an increase in the percentage of mechanical availability and reduction of $47.0 \%$ in the consumption of hydraulic oil from Skidder in the maturation stage. Also, the average time between failures and repairs increased in the maturation stage, caused by a quality improvement of maintenance activities. Moreover, in the maturation stage there was an increase of $45.0 \%$ in the proactive maintenance index. Additionally, it was verified that the hourly maintenance cost was reduced by $8.0 \%$ between the maturation and stabilization stages, underlining the WCM system's potential to improve maintenance activities in the forest skidding operation. These results show that the WCM system can contribute to safety in wood harvesting operations, increasing the Skidder mechanical availability and a reducing the production costs.
\end{abstract}

Keywords: maintenance practices, preventive maintenance, mechanical

\section{Introduction}

In the forest sector, harvest is one of the most representative activities from the economic point of view, due to its representation in the product final cost and also due to the risk of loss involved in this activity (Duarte, 1994; Jacovine et al., 1997). Thus, increasing mechanization level of harvesting operations contributes to high productivity, and also improves results considering safety, environment and costs issues (Ledoux, 2010).

In addition, during the last decades the mechanization of forest harvesting operations has evolved, encouraged by the opening of the market for imports. Important to realize that, by using machines and equipment with complex technologies, and because these operations are affected by variables such as operator training, forest conditions, mechanical availability and operational efficiency, it requires an efficient maintenance management model and specialized manpower that allow the maintenance of the expensive assets present in forest operations (Bramucci \& Seixas, 2002; Simões \& Fenner, 2010; Lopes \& Pagnussat, 2017).

In this context, mechanical maintenance represents the combination of administrative and technical activities required to maintain an equipment, installation and other physical assets under operating conditions while maintaining their activities (Muchiri et al., 2011). Kardec et al. (2002) points out that maintenance has the attribution of restore the original conditions of the equipment and guarantee its availability, taking into account the production process, with reliability, safety, environmental preservation and adequate costs. Paccola (2011) adds that maintenance consists of managing teams and other resources that are available in the organization and 
in the maintenance area. Concerning mechanical maintenance, authors that provided important scientific contributions were Kardec and Nascif (2013); Dario et al. (2014); Kardec et al. (2002).

Presently, maintenance concepts include "world-class maintenance" (WCM), which addresses preventive maintenance, aiming achieve world-class maintenance through process leadership, which aggregates activities from other maintenance programs such as "total productive maintenance" (TPM) (Yamashina, 2000, Mishra et al., 2006, Slack et al., 2008, Mishra et al., 2015).

Thereby, considering the importance of maintenance for forest harvest, and also the relevance of studies that contribute to development of forest operations, aiming increase mechanical availability of equipment, productivity and cost reduction, the objective of this work was to evaluate technical and economic feasibility of the introduction of a world-class maintenance system (WCM) in Skidder forest operations.

\section{Material and Methods}

This research was driven in a pulp and paper company located in the state of Paraná/Brazil. In the study area, the machines were operating in plantations of Eucalyptus grandis and Pinus taeda species, with 7 and 17 years respectively, under shallow cutting regime, individual average volume of trees varying from 0.36 to $0.42 \mathrm{~m}^{3}$, respectively. Additionally, the relief of these areas is smoothly wavy.

The study object was a Skidder machine with nominal horsepower of $250 \mathrm{hp} / 180 \mathrm{KW}$, Cummins QSC8 Tier III engine (diesel), operating weight of 22.7 tons, equipped with a claw of $1.95 \mathrm{~m}^{2}$ of area, tire wheels and 1501 hour worked (Figure 1). This Skidder is used to drag trees from the cutting area to the edge of the field road, leaving the wood ready for processing (Minette et al., 1996).

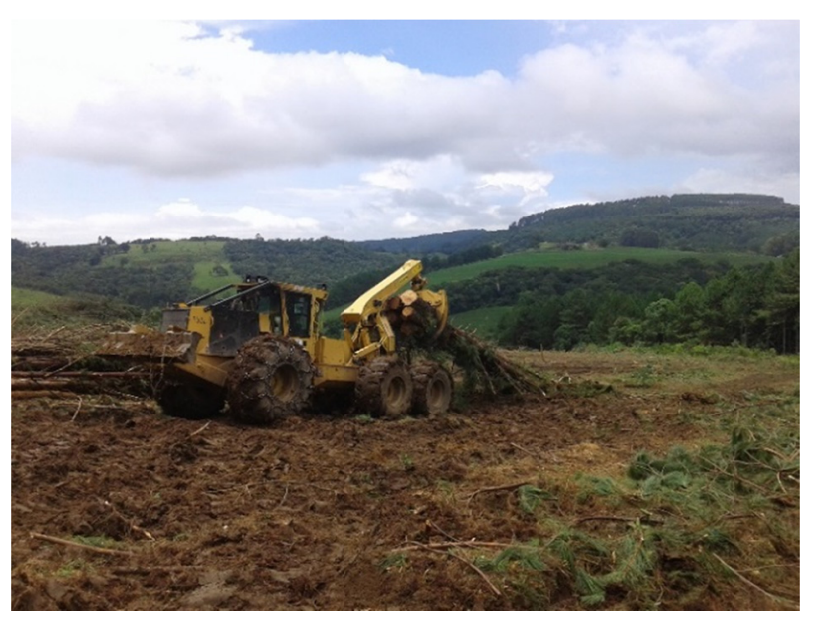

Figure 1. Skidder machine studied in this work

Moreover, the research data in this study is drawn from the logbooks of the equipment, during a period of 18 months with the intention of approaching 6 months for each stage and later being divided into three stages of the same duration: implantation, maturation and stabilization of WCM activities. It is important to remember that the implementation stage was characterized by the period in which the training activities of mechanics and operators began, as well as the acquisition of all the necessary structure for the WCM maintenance system. The maturation period was characterized by the improvement of the WCM, where the volume of parts that were supposed to have at the field level, level of training of employees, types of maintenance to be implemented, etc. were adequate. Finally, the stabilization period was characterized by the progress of the WCM system without the need for adjustments.

Also, the research team visited the company monthly, aiming to check the progress of mechanical maintenance operations. In this way, each visit to the company lasted 10 days, with visits to field and office operations, each of which was held once a month during the 18 months, so that the data collection counted for about 180 days.

The maintenance activities of WCM system executed were:

Corrective maintenance: performed for immediate correction of any failure, such as broken pins, adjustments of clearances, exchange of bearings, among others; 
$>$ Preventive maintenance of lubrication system: revisions of oil change and filters change according the machine manuals or the definition of maintenance sector;

Failure analysis: an activity that counts on a multidisciplinary team, composed of people whit know how of the process and methods, with rounds of discussion searching the main cause and definitive solution of the problem. In addition, the failure analysis is a planned action that aims to prevent and evaluate nonconformities, seeking to identify the possibility that something happens outside the planned.

$>\quad$ Preventive maintenance: maintenance cycle performed during eight weeks checking the equipment, where in each week, a series of components where revised;

$>$ Strategic reviews: performed during the dawn by specific teams composed of mechanics and welders. It occurs in an interval of approximately three weeks, where the teams visit the equipment during two days, performing heavy and complex works like solders.

Regarding technical analysis, we calculated the indicators of mechanical availability, average hydraulic oil consumption, average time between failures, average repair time and proactive maintenance index.

The mechanical availability is defined as the percentage of the programmed service time in which the machine is available to perform a certain activity, ignoring the time spent in maintenance (Rocha et al., 2009; Simones \& Fenner, 2010; Santos et al., 2013; Lopes et al., 2016; Guedes et al., 2017) and is calculated by the expression:

$$
\mathrm{MA}=(\mathrm{WH}-\mathrm{MH}) / \mathrm{WH} \times 100
$$

Where, MA = Level of Mechanical Availability (\%); WH = Working Hours; and MH = Maintenance Hours.

The average consumption of hydraulic oil was calculated using an equation based on Simões et al. (2010); Nascimento et al. (2011) and Simões et al. (2014):

$$
\mathrm{HOC}=\mathrm{MHO} / \mathrm{H}
$$

Where, $\mathrm{HOC}=$ Average Hydraulic Oil Consumption (liters/hour); MHO= Monthly Consumption of Hydraulic Oil (liters); and $\mathrm{H}=$ Monthly Working Hour.

The mean time between failures (MTBF) is calculated by the relation between the total number of working hours available for the machine or equipment and the number of corrective maintenances performed in the period, obtained by the expression (Kumar et al., 1999; Braglia et al., 2012, Wienker et al., 2016):

$$
\mathrm{MTBF}=\mathrm{AWH} / \mathrm{CM}
$$

Where, $\mathrm{MTBF}=$ Average Time Between Failure (hours); AWH = Available Working Hours; and CM= number of corrective maintenances performed.

The mean time to repair (MTTR) is the ratio of the hours of corrective maintenance performed in relation to the number of corrective maintenances performed in the analyzed period, and is calculated using the following expression (Meng, 1995; Braglia et al., 2012):

$$
\mathrm{MTTR}=\mathrm{HCC} / \mathrm{CM}
$$

Where, MTTR = Mean Time to Repair (hours); HCC $=$ Hours of Corrective Maintenance; and CM = number of corrective maintenances performed.

The proactive maintenance index (PI) is the ratio between the proactive maintenance time (preventive maintenance) and the total maintenance time in each machine or equipment, which is calculated using the following expression:

$$
\mathrm{PI}=(\mathrm{PMT} / \mathrm{TMT}) \times 100
$$

Where, PI = Proactive Maintenance Index (\%); PMT = Proactive maintenance time (hours); and TMT = Total maintenance time (hours).

Regarding economic analysis, the maintenance cost for the machine was calculated considering the costs of staff, materials, external services and support, these are the variables that the company under study uses in its operations.

The staff cost aggregates expenses with salaries, social charges, benefits provided by the company (such as profit sharing), and expenses with training and retraining of the maintenance team. The monthly total values were divided by the number of hours worked with the equipment studied, according to the equation:

$$
\mathrm{SC}=(\mathrm{S}+\mathrm{SC}+\mathrm{B}+\mathrm{TR}) / \mathrm{H}
$$

Where, $\mathrm{SC}=$ Staff Cost (\$/hour); $\mathrm{S}=$ Salaries $(\$) ; \mathrm{SC}=$ Social Charges $(\$) ; \mathrm{B}=$ Benefits $(\$) ; \mathrm{TR}=$ trainings $(\$)$ and $\mathrm{H}=$ Monthly Working Hours. 
The material costs refer to consumption of spare parts, water, fixed capital, warehouse management and costs of the purchasing sector (Equation 7):

$$
\mathrm{MC}=\mathrm{M} / \mathrm{H}
$$

Where, $\mathrm{MC}=$ Material Costs $(\$ /$ hour $) ; \mathrm{M}=$ Materials $(\$)$ and $\mathrm{H}=$ Monthly Working Hours.

The cost of external services refers to the monthly values of contracts with outsourced companies responsible for services such as equipment washing, welding, oil analysis and other activities, which were then divided by the hours worked during the analyzed period (Equation 8).

$$
\mathrm{CES}=\mathrm{OC} / \mathrm{H}
$$

Where, CES $=$ Cost of External Services ( $\$$ /hour); OC $=$ Outsourced Companies $(\$)$ and $H=$ Monthly Working Hours.

Regarding the support costs, we considered like input costs with support vehicles, truck train, welding cart, and warehouse, which composed the following equation.

$$
\mathrm{SUC}=\mathrm{IC} / \mathrm{H}
$$

Where, $\mathrm{SUC}=$ Support Cost $(\$ /$ hour $) ; \mathrm{IC}=$ Input Costs and $\mathrm{H}=$ Monthly Working Hours.

Then, for the total cost of maintenance, all the costs detailed above were considered together and calculated by the expression:

$$
\mathrm{TMC}=\mathrm{SC}+\mathrm{MC}+\mathrm{CSE}+\mathrm{CA}
$$

Where, $\mathrm{TMC}=$ Total Maintenance $\operatorname{Cost}(\$ / \mathrm{he}) ; \mathrm{SC}=\operatorname{Staff} \operatorname{Cost}(\$ / \mathrm{he}) ; \mathrm{MC}=$ Material Cost $(\$ / \mathrm{he}) ; \mathrm{CES}=$ Cost of External Services $(\$ /$ he) and SUC $=$ Support Cost $(\$ /$ he $)$.

For the statistical validation of the work, a completely randomized design with factorial arrangement was used, where three treatments with six replications were tested. The treatments represented the combination of Skidder machine applied to the three stages of WCM system (implantation, maturation and stabilization). Equally, for the MTTR, the same type of analysis was performed, however, a total of two treatments with five replications were applied, and the treatments represent the combination of Skidder machine applied to the two stages (maturation and stabilization). During the implementation period of the WCM it was not possible to collect the MTTR information, since the operators were still in training, in this way, we opted for the exclusion of the period so as not to prejudice the analysis.

Additionally, an Analysis of Variance was applied to the obtained results. First, the variances of the treatments were evaluated for their homogeneity using the Bartlett test. Then, the variables whose variances were homogeneous had the effects of the treatments tested using the F test. Finally, when the results revealed statistically significant differences between treatment means, the means were compared by the Tukey's test ( $p$ value $<0.05$ ).

\section{Results and Discussion}

The WCM maintenance system was generally successful. As can be seen in Figure 2, the mechanical availability of Skidder increased in response to the investment made, but it was not possible to detect significant statistical difference between the stages (Implantation 89.8, maturation 91.5, Stabilization 90.9) by the Tukey test ( $\mathrm{p}$ value $<0.05$ ). However, this result has practical relevance, since it allows to infer that with preventive actions it is possible to increase the mechanical availability of the forest extraction machines. 


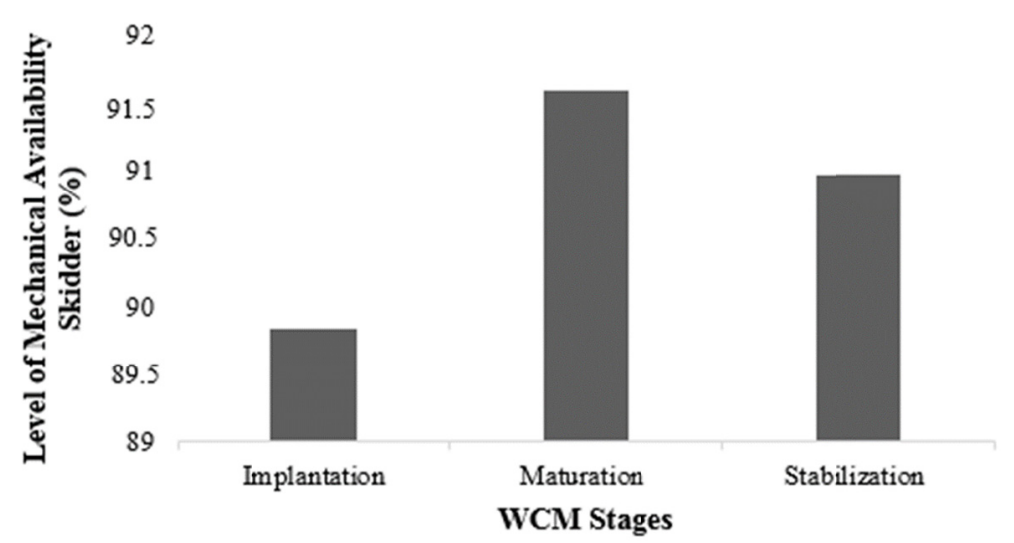

Figure 2. Skidder mechanical availability studied in the WCM system stages

This result can be explained by the fact that a field warehouse was installed containing the main turning parts, so that parts were available in the field when there was some corrective maintenance, thus avoiding unnecessary waste of time waiting for the parts came from others locations.

At the same time, the training of staff (mechanics and operators) was another factor that contributed to the increase of the mechanical availability. In addition, preventive maintenance and strategic maintenance also played an important role in the improvement of this indicator, where weekly interventions were performed checking, replacing, lubricating, repairing and re-fitting the machine components, which allowed a greater flow of activity.

Generally speaking, the results of the mechanical availability presented values above $85 \%$, close to that obtained by Rocha et al. (2009) and Simões et al. (2014), who studied forest harvesting machines. The causes that most affected mechanical availability were similar to those found in Rocha et al. (2009), where the inadequate operation of the machine and incorrect lubrication resulted in a decrease of mechanical availability. Important to realize that the lack of cleaning of the machine as well as the non-fulfilment of the maintenance procedures also contribute to the reduction of mechanical availability, reducing the reliability of the operation, equipment life and operational safety.

In the Figure 3 is shown the results of Skidder hydraulic oil consumption in the three stages evaluated. It is a reduction in the consumption of hydraulic oil in the maturation stage of the WCM system, also showing significant difference (Implantation 0.19, maturation 0.10, Stabilization 0.07) by the Tukey test $\left(\mathrm{p}_{\text {value }}<0.05\right.$ ).

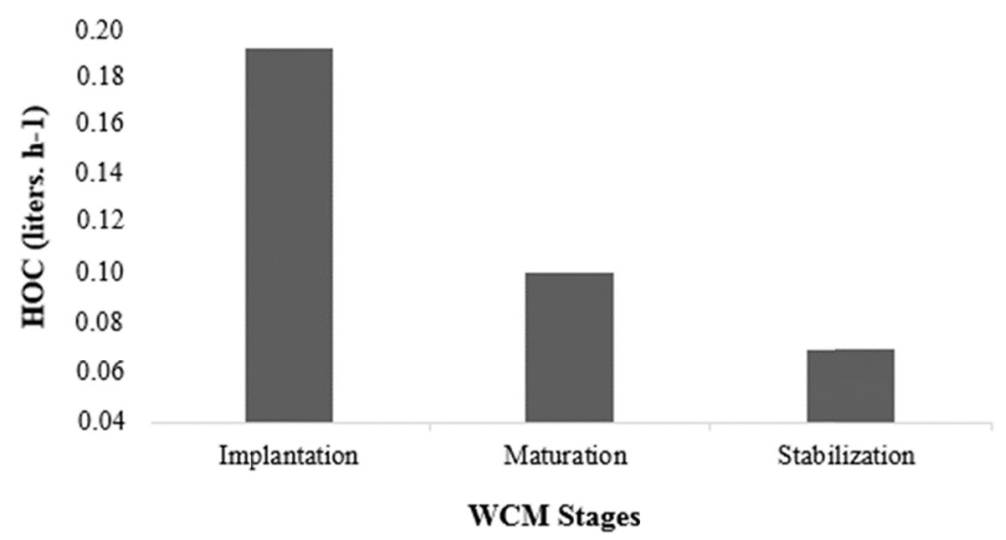

Figure 3. Skidder hydraulic oil consumption (HOC) studied in the WCM system stages

These values are mainly due to the performance of preventive maintenance, which eliminated repairs and also to the occurrence of worn hoses, as well as the reestablishment of parts that had slack, which caused leakage of hydraulic oil, causing premature wear. As a result, there were a reduction on the consumption of hydraulic oil (0.12 liters of hydraulic oil per hour worked). 
Regarding the results of the MTBF index, shown in Figure 4, the WCM system allows a considerable increase in the interval of occurrence between failures of the studied machine, showing improvement of $31.0 \%$ in the stabilization stage comparing to the implantation stage, showing significant difference (Implantation 31.64a, maturation $40.85 \mathrm{~b}$, Stabilization $45.90 \mathrm{~b})$ by the Tukey test $\left(\mathrm{p}_{\text {value }}<0.05\right)$.

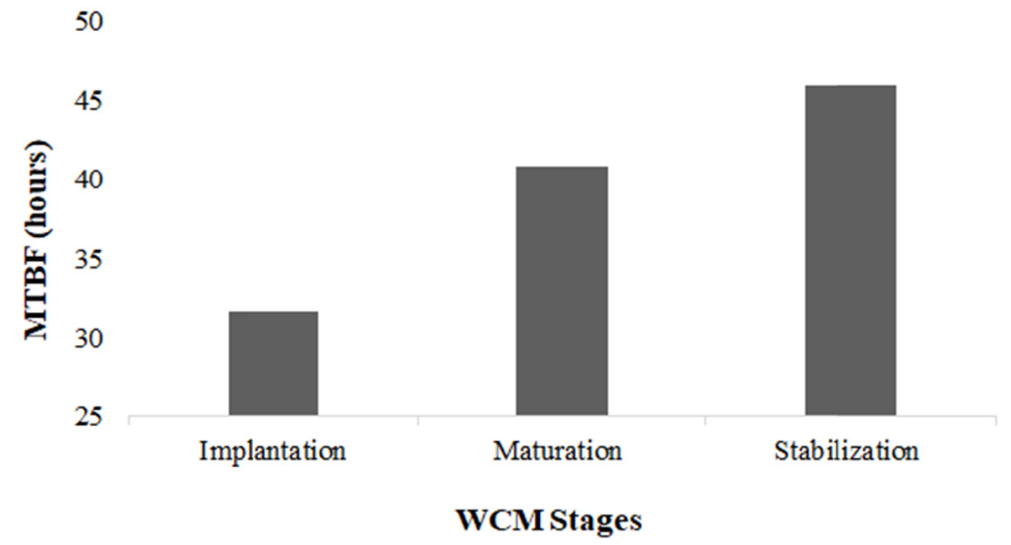

Figure 4. Mean Time Between Failure (MTBF) for Skidder machine studied in the WCM system stages

This increase in the intervals between failures can be explained by the preventive maintenances, staff training and implantation of the field warehouse. Must be remembered that, during the period of implantation, the employees still did not have adequate training, field storage, and an ideal dimensioning of the parts needed for the activity.

In this way, a variation between 31 and 45 hours was considered, considering the adverse operating conditions, working up to 18 hours a day throughout the year. Almeida (2013) studying methodologies of maintenance in agricultural tractors obtained an average MTBF of 509, 239 and 122 hours in tractors of $135 \mathrm{CV}, 115 \mathrm{CV}$ and $100 \mathrm{CV}$, respectively. It is important to remember that, besides the small size of the tractors, they performed slight operations, different from the forest operations, in which the machines operated under hard conditions.

The values presented in Figure 5 show the results obtained for the MTTR indicator (mean time to repair) in the maturation and stabilization stages of the WCM system. As can be seen, there was an increase in the machine repair times, which presented an average 14\% higher during the stabilization period of the WCM system. However, these results did not present a significant difference by the Tukey test $\left(\mathrm{p}_{\text {value }}<0.05\right)$.

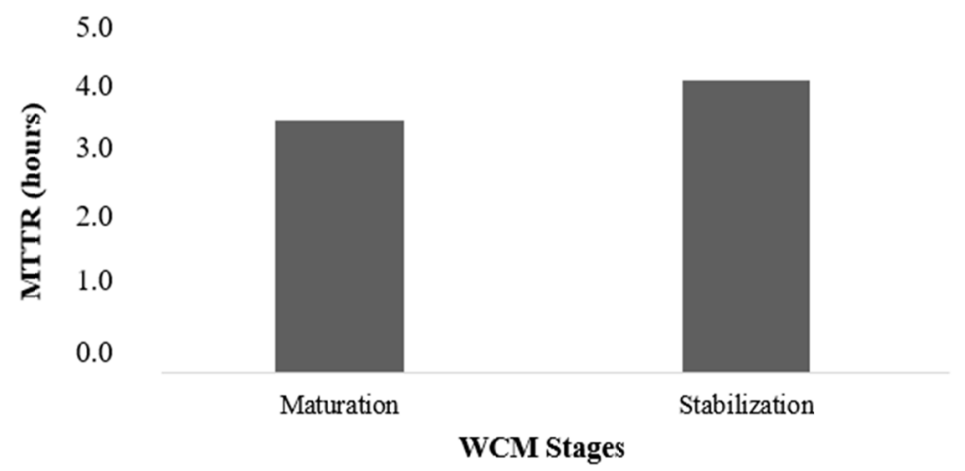

Figure 5. Mean time to repair (MTTR) for the Skidder machine studied in the WCM system stages

In essence, the results show that the WCM system allowed a change in the company's culture, as evidenced by the increase in preventive maintenance (total increase of more than $50 \%$ ). There was statistically difference by the Tukey test $\left(\mathrm{p}_{\text {value }}<0.05\right)$. 


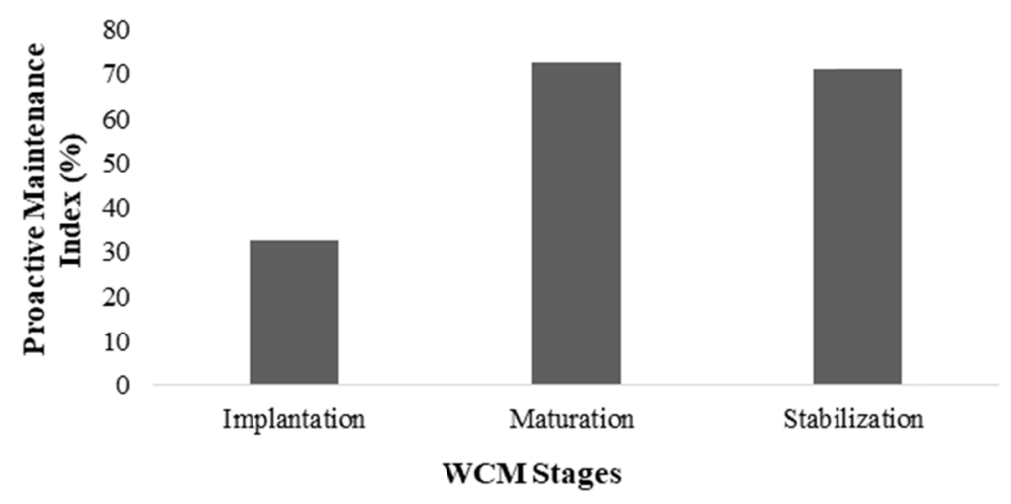

Figure 6. Proactive maintenance index for the skidder machine studied in the WCM system

The increase was a result of various preventive maintenance interventions carried out with the introduction of the WCM system, which contributed to a reduction in the number of failures to all studied machines. Notably, in the WCM system, whenever the components such as hoses, pins, repairs, bearings, pistons, among others, presented wear, they were evaluated during preventive maintenance and, if necessary, these items were replaced, thus reducing the occurrence of maintenance (non-scheduled corrective maintenance).

When analyzing from the economic perspective, the stabilization stage of the WCM system presented a reduction of $5 \%$ in maintenance cost per hour worked compared to the implantation stage, and a reduction of $8 \%$ compared to maturation stage, yet both results without statistical differences by the Tukey test $\left(\mathrm{p}_{\text {value }}<0.05\right)$.

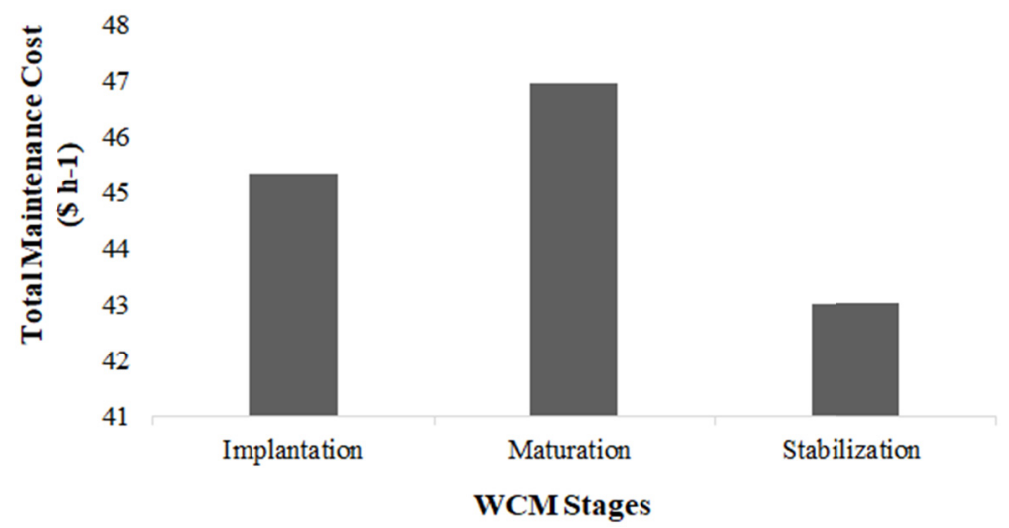

Figure 7. Total maintenance cost for the skidder machine studied in the WCM system

This result is explained by the investment in hiring specialized staff, training operators and mechanics, purchase parts and tools for inventory formation, since over time it was possible to improve the structure of the warehouse. Indeed, these numbers should be considered relevant since, with the introduction of a maintenance system based on preventive maintenance, there was an effective reduction in the cost of machine maintenance, which can represent thousands of dollars per year and guarantee the return of investments made.

The values obtained were above the costs observed by Lopes et al. (2014), studying the Skidder forest tractor in the extraction of wood, where they observed an average maintenance cost of $\$ 26.88$ per hour worked, totaling approximately $50 \%$ of the total cost of the machine.

Overall, other studies have demonstrated that the sensitivity of the type of maintenance used depended on the operating conditions of each company, such as training level of mechanics and operators, logistics of supply of parts and fuels, size of the maintenance structure in the field, among others (Malinovski et al., 2006; Fiedler et al., 2008; Lopes et al., 2008; Fernandes et al., 2009; Schettino et al., 2015), which together or alone end up neutralizing any chance of cost reduction and increased availability mechanics of wood harvesting machines. 


\section{Conclusions}

In the final analysis, the WCM system provided an increase in the mechanical availability of Skidder machine, indicating the possibility of increase the wood drag operation, since more hours of the machine are available for the operation.

Besides, preventive maintenance proved to be fundamental for the results obtained, once allowed the realization of terminal re-fitting, replacement of hoses and also repairs in the ones that presented wear, thus avoiding oil leakage during operation.

Regarding the MTBF, MTTR and proactive maintenance index indicators, the results were worse during the first stages, explained by the lack of structure in the initial months. However, in the stages of maturation and stabilization, the results surpassed the marks obtained in the implantation stage, showing the evolution of the WCM system in a short period of time.

All things considered, the reduction of Skidder's maintenance cost in the stabilization stage demonstrates that the application of preventive maintenance practices offers concrete possibilities of better financial results to the company by reducing its production costs.

Also, the WCM system improved safety results in the operations, contributing to a longer machine life.

\section{References}

Almeida, F. E. F. (2013). Análise comparativa entre metodologias de manutenção de tratores agrícolas (Coimbra, 108f, Dissertação, ISEC, Mestrado em Equipamentos e Sistemas Mecânicos, Instituto Superior de Engenharia de Coimbra, Coimbra).

Braglia, M., Carmiganini, G., Frosolini, M., \& Zammori, F. (2012). Data classification and MTBF prediction with a multivariate analysis approach. Reliability Engineering and System Safety, 97, 27-35. https://doi.org/ 10.1016/j.ress.2011.09.010

Bramucci, M., \& Seixas, F. (2002). Determinação e quantificação de fatores de influência sobre a produtividade de "harvesters" na colheita florestal. Scientia Forestalis, 62, 62-74.

Busso, C. M., \& Miyake, D. I. (2013). Análise da aplicação de indicadores alternativos ao Overall Equipment Effectiviness (OEE) na gestão de desempenho global de uma fábrica. Revista Produção Online, 23(2), 205-225. https://doi.org/10.1590/S0103-65132012005000068

Dario, M., Silva, E. M., Sacomano, M. N., \& Pires, S. R. I. (2014). Indicadores de desempenho, práticas e custos da manutenção na gestão de pneus de uma empresa de transportes. Revista Produção Online, 14(4), 1235-1269. https://doi.org/10.14488/1676-1901.v14i4.1450

Duarte, R. C. G. (1994). Sistemas de corte florestal mecanizado (p. 21). Viçosa, MG: UFV.

Fernandes, H. C., Lopes, S. E., Teixeira, M. M., Minette, L. J., Rinaldi, P. C. N., \& Bernardes, A. M. (2009). Avaliação das características técnica e econômica de um sistema de colheita florestal de árvores inteiras. Scientia Forestalis, 37(83), 225-232.

Fiedler, N. C., Rocha, E. B., \& Lopes, E. S. da. (2008). Análise da produtividade de um sistema de colheita de árvores inteiras no Norte do Estado de Goiás. Floresta, 38(4), 577-586. https://doi.org/10.5380/ rf.v38i4.13153

Guedes, L. G. Amaral, E. J. do, Leite, E. S. da., Fernandes, H. C., \& Sant'Anna, C. M. de (2017). Avaliação do desempenho e custos de dois sistemas de cabos aéreos na extração de madeira de eucalipto. Ciência Florestal, 27(2), 571-580. https://doi.org/10.5902/1980509827737

Jacovine, L. A. G., Cardoso, M. C., Souza, A. P., \& Rezende, J. L. P. (1997). Reflexos da má qualidade na colheita florestal semi-mecanizada (pp. 296-308). Simpósio Brasileiro Sobre Colheita e Transporte Florestal, 3, Vitória. Anais... Vitória: Sociedade de Investigações Florestais.

Kardec, A., Nascif, J. A., \& D'aquino, B. T. (2002). Gestão estratégica e Técnicas preditivas. Rio de Janeiro, RJ: Qualitymark.

Kardec, A., \& Nascif, J.A. (2013). Manutenção função estratégica (4th ed.). Rio de Janeiro, RJ: Qualitymark.

Kumar, U. D., Knezevic, J., \& Crocker, J. (1999). Maintenance free operating period-an alternative measure to MTBF and failure rate for specifying reliability? Reliability Engineering and System Safety, 64, 127-131. https://doi.org/10.1016/S0951-8320(98)00048-9 
LeDoux, C. B. (2010). Mechanized systems for harvesting eastern hardwoods (p. 13). Newtown Square: U.S. Department of Agriculture, Forest Service, Northern Research Station. https://doi.org/10.2737/ NRS-GTR-69

Lopes, E. S. Oliveira, D. de, \& Sampietro, J. A. (2014). Influence of wheeles types of a skidder on productivity and cost of the forest harvesting. Floresta, 44(1), 53-62. https://doi.org/10.5380/rf.v44i1.31356

Lopes, E. S., Diniz, C. C. C., Serpe, E. L., \& Cabral, O. M. J. V. de. (2016). Efeito do sortimento da madeira na produtividade e custo do forwarder no desbaste comercial de Pinus taeda. Scientia Forestalis, 44(109), 57-66. https://doi.org/10.18671/scifor.v44n109.05

Lopes, E. S., \& Pagnussat, M. B. (2017). Effect of the behavioral profile on operator performance in timber harvesting. International Journal of Forest Engineering, 1-6.

Lopes, S. E. Carlos, F. H., Santos, N. T., \& Cristina, P. (2008). Avaliação técnica e econômica de uma garra traçadora operando em diferentes produtividades. Scientia Forestalis, 36(79), 215-222.

Malinovski, R. A., Malinovski, R. A., \& Malinovski, J. R. (2006). Análise das variáveis de influência na produtividade das máquinas de colheita de madeira em função das características físicas do terreno, do povoamento e do planejamento operacional florestal. Floresta, 36(2), 169-182. https://doi.org/10.5380/ rf.v36i2.6459

Meng, F. C. (1995). Comparing the mtbf of four systems with standby components. Microelectron, 35(7), 1031-1035. https://doi.org/10.1016/0026-2714(95)90861-J

Minette, L. J. (1996). Análise de fatores operacionais e ergonômicos na operação de corte florestal com motosserra (211f, Tese, Doutorado em Ciência Florestal, Universidade Federal de Viçosa, Viçosa).

Mishra, R. P., Kodali, R. B., Gupta, G., \& Mundra, N. (2015). Development of a framework for implementation of world-class maintenance systems using interpretative structural modeling approach. Procedia CIRP, 26, 424-429. https://doi.org/10.1016/j.procir.2014.07.174

Mishra, R. P., Anand. G., \& Kodali, R. B. (2006). Development of a framework for world-class maintenance systems. Journal of Advanced Manufacturing Systems, 5, 141-165. https://doi.org/10.1142/S02196867 06000807

Muchiri, P., Pintelon, L., Gelders, L., \& Martin, H. (2011). Development of maintenance function performance measurement framework and indicators. International Journal of Production Economics, 131(1), 295-302.

Nascimento, A. C., Leite, A. M. P., Soares, T. S., \& Freitas, L. C. de. (2011) Avaliação técnica e econômica da colheita florestal com feller-buncher. Revista Cerne, 17(1), 9-15.

Paccola, J. E. (2011). Manutenção e operação de equipamentos móveis (1st ed., p. 272). São José dos Campos, SP.

Rocha, E. B., Fiedler, N. C., Alves, R. T., Lopes, E. S., Guimarães, P. P. \& Peroni, L. (2009). Produtividade e custos de um sistema de colheita de árvores inteiras. Revista Cerne, 15(3), 372-381.

Santos, P. H. A., Souza, A. P., Marzano, F. L. C., \& Minette, L. J. (2013). Produtividade e custos de extração de madeira de eucalipto com clambunk skidder. Revista Árvore, 37(3), 511-518. https://doi.org/10.1590/ S0100-67622013000300014

Schettino, S. Minetti, L. J., \& Souza, A. P. (2015). Correlação entre volumetria de florestas de eucalipto e produtividade e custos de máquinas de colheita de madeira. Revista Árvore, 39(5), 935-942. https://doi.org/10.1590/0100-67622015000500016

Silva, E. M. Machado, C. C., Minette, L. J., Souza, A. P., Fernandes, H. C., Silva, M. L., \& Jacovine, L. A. (2010). Avaliação técnica e econômica do corte mecanizado de Pinus sp. com Harvester. Revista Árvore, 34(4), 745-753. https://doi.org/10.1590/S0100-67622010000400019

Simões, D., \& Fenner, P. T. (2010). Avaliação técnica e econômica do Forwarder na extração de madeira em povoamento de eucalipto de primeiro corte. Floresta, 40(4), 711-720. https://doi.org/10.5380/ rf.v40i4.20323

Simões, D., Fenner, P. T., \& Esperancini, M. S. T. (2014). Produtividade e custos do Feller-buncher e processador florestal em povoamento de eucalipto de primeiro corte. Ciencia Florestal, 20(3), 621-630. https://doi.org/10.5902/1980509815742

Slack, N., Chambers, S., \& Johnston, R. (2008). Administração da produção (2nd ed.). Atlas: São Paulo. 
Wienker, M., Henderson, K., \& Volckerts, J. (2016). The computerized maintenance management system an essential tool for world class maintenance. Procedia Engineering, 138, 413-420. https://doi.org/10.1016/ j.proeng.2016.02.100

Yamashina, H. (2000). Challenge to world class manufacturing. International Journal of Quality of Reliability Management, 12(34), 30-31. https://doi.org/10.1108/02656710010304546

\section{Copyrights}

Copyright for this article is retained by the author(s), with first publication rights granted to the journal.

This is an open-access article distributed under the terms and conditions of the Creative Commons Attribution license (http://creativecommons.org/licenses/by/4.0/). 